\title{
Scientific Paradigm of the New Industrialization as a Theoretical Framework for Economic Growth of Regions
}

\author{
Yakov Petrovich Silin \\ Ural State University of Economics, \\ Head of the University \\ Ekaterinburg, Russia \\ odo@usue.ru
}

\author{
Evgeny Georgievich Animitsa \\ Ural State University of Economics, \\ Chair of the Department for Regional and Municipal \\ Economy and Management \\ Ekaterinburg, Russia \\ ega@usue.ru
}

\author{
Natalia Valerievna Novikova \\ Ural State University of Economics, \\ Associate Professor of the Department for Regional and Municipal Economy and Management \\ Ekaterinburg, Russia \\ novikova@usue.ru
}

\begin{abstract}
The article addresses core provisions of the emerging scientific paradigm of the new industrialization. The need for Russia and its regions to switch over to a model of the new industrialization is not open to question. However, there is no clear understanding of the processes of the new industrialization and their economic size. Finding ways and mechanism for implementing the process of the new industrialization on the scale of the country and its regions remains an issue. In the course of the research, the authors systematised conceptual provisions of the scientific paradigm of the new industrialization to create a theoretical framework for economic growth and development of the regions.
\end{abstract}

Keywords - industrialization, new industrialization, scientific paradigm, the scientific paradigm of the new industrialization, economic space of the region, economic development of regions

\section{INTRODUCTION}

Russia's rapid transition from an administrative and planned economy to a market-driven economy of a liberal and monetary nature led to socio-economic shocks of various depth and duration. The key features of such transition were as follows: a marked decline in macroeconomic indicators; sluggish economic growth; large-scale depreciation of fixed assets; increase in the simplification of the production structure; progressive catch up with world leaders; significant decline in consumer demand; highly explosive polarization of the population in terms of income; creeping prices for goods and services; real possibility of mass poverty; increase in heterogeneity of the economic space, etc.
These and other negative trends clearly indicate that the reasons for their emergence lie in the very essence of the existing model of economic management and administration, implemented by socio-economic policies at the federal and regional levels.

Scientists, experts, officials of federal and regional authorities responsible for economic policy started the agonizing quest for searching the ways out of the current situation, offering various forms and options for the transition to sustainable and systemic economic growth, elaborating development strategies as a response to the historic challenge that our country has faced at the turning point of the centuries.

It becomes obvious that our country currently has no other way to overcome its technological backwardness and technological dependence but to implement a policy of the new industrialization, being adequate to today's challenges and the prevailing geo-economic and geopolitical situation.

However, the scientific paradigm of the new industrialization is currently at the stage of formation for the following reasons. Firstly, the very notion of the "new industrialization" is relatively new to domestic science. Secondly, the unformed terminological apparatus leads to the use of concepts different in writing (for example, "reindustrialization", "new industrialization", "neoindustrialization"), but they are close, single-order in content and include such terms as "superindustrialization" and "advanced industrial development". 
This article aims to systematise key conceptual provisions of the scientific paradigm of the new industrialization of the country and its regions.

\section{MAterials AND Methods (Model)}

During the research, we used a comparative analysis methodology.

\section{RESULTS AND DISCUSSION}

In modern dictionaries, the notion of the paradigm (from Greek paradeigma - 'example', 'pattern') is treated as a set of prerequisites that determine the specific scientific research (knowledge) and recognised at this stage [1, p. 332]. The concept of the scientific paradigm and scientific revolutions of $\mathrm{T}$. Kuhn is recognized by leading scientists of the modern age as very informative and promising, that is why we use it in our research.

T. Kuhn defines the paradigm as follows: "With paradigms, I mean universally recognized scientific achievements that, for a certain time, provide a model of posing the problems and their solutions for a scientific community [2, p. 17]

Therefore, the scientific paradigm is norms and patterns of scientific thinking that becoming a tradition in a given scientific community. Paradigms represent certain scientific stereotypes, patterns of thinking, within which scientists at some time solve their research tasks.

The scientific paradigm includes the basic prerequisites, research methods adopted in any given science, as well as the scientists' views on ways of solving scientific issues. The development of any field of knowledge is a succession of scientific paradigms, during which the basic theoretical concepts are revised.

The scientific paradigm of the new industrialization (neoindustrialization) is in the stage of formation in connection with the recent appearance of this concept and the object of scientific knowledge.

For its construction, we consider it necessary and reasonable to turn to the key provisions of the economic theory of industrialization, since neoindustrialization, "on the one hand, is the continuation of industrialization, and on the other, is its denial" [3, p. 284].

Scientists working within the economic theory of industrialization refer to the definition of the classic of the economic theory by A. Smith, who classified the industry as the occupation of making machines that allow "one person to do the work of many people", i.e. two or three or more workers [4, p. 17]. It should be noted that the definition presented was given at the time when the machine industry was just arising.

Since then, stricter scientific criteria have emerged, according to which "everything connected with a saving of labor is related to the industry. ... Following a classical understanding based on the economic laws of our era, the industry is a way of replacing the labor-intensive one with the machine-intensive one" [5, p. 49].

In economic dictionaries, the industry (from Latin industria - activity) is treated as a production sector [6, p. 338], mainly factory-and-works and applying machinery [7, $\mathrm{p}$. 318].

The derived concept of industrialization (from Latin industria - 'activity') is seen as shifting the country's economy to industrial basis, the creation of large-scale machine production in the national economy or its separate field, and a significant increase in the share of industrial production in the economy. The industrialization of a particular field, for example, agriculture, means its transition to an industrial (machine) basis [6, p. 337].

Industrialization is a significant increase in the share of industrial fields in the structure of the economy and the process of transition from a mainly agrarian to a mainly industrial economy [8, p. 160-161].

Modern economic science distinguishes between two models of industrialization.

The first model brings to the forefront the creation of industrial complexes designed to saturate and structure the domestic market using locally produced products, and only then to expand their exports. The second one is exportoriented, it focuses on international industrial specialization and cooperation, with the development of which it places hopes to saturation of the domestic market and its structuring.

A crucial role in the implementation of both models is played by the state: it determines the main parameters and aims of industrialization, as well as the means to achieve them; on the basis of state investments, the development of economic and social infrastructure is carried out; the state conducts large-scale industrial entrepreneurship; provides a range of assistance to private entrepreneurship.

An unequal natural resource endowment, the use of which serves as a source of foreign exchange, has an influence on the choice of the industrialization model.

Specific forms of industrialization and its results are largely determined by the economic strategy chosen in the country.

Industrialization is a long process (and not a "revolution"), which had its own specifics in the countries of the "classical" (Western European countries) and "non-classical" capitalism.

It is generally accepted to single out several stages (phases) of industrialization, among which are: 1) preindustrial stage (agrarian society, traditional economy); 2) proto-industrial stage (forerunner of industrialization itself); 3) early industrial stage (the first phase of the development of industrial society) and the late industrial phase (modern industrial society).

In the USSR, in 1925-1930, a discussion on the study of the industrialization process was organized, which revealed a number of central theoretical problems that are relevant at the present time $[9,10]$. The key directions of scientific discussion 
are the choice of the basic concept, means, and methods of industrialization.

In the 20s of the 20th century, conceptual construction of industrialization was reduced to two main approaches.

The first approach (industrialization after V.A. Bazarov) involved the solution of the problem of industrialization through strengthening the results of the new economic policy by stimulating consumption and the consumer sector, which meant stimulating demand and savings, which then had to be directed towards the problem of deploying production in the public sector [11].

The second approach (industrialization after F.E. Dzerzhinsky, L.D. Trotsky, and V.I. Stalin) meant the reduction of the new economic policy, the strengthening of control over rural resources and their subordination to the task of industrialization. For this, large collective farms in the countryside were needed that facilitated the control and concentration of the resource. The task was not just to industrialize, create a modern industry almost from scratch, since former bourgeois industrial enterprises were destroyed during the civil war or eked out a precarious existence and lagged far behind technically and technologically from the Western countries that took advantage of the First World War for stimulating the development of their industry.

The implementation of the second approach assumed the formation of the heavy industry at the expense of rural resources, urbanization, the creation of institutional conditions for improving the educational and scientific level of Russia, in order to give the agricultural industry new machinery, equipment, to develop infrastructure, and to create the necessary defense of the country.

Our research of scientific sources showed the lack of unity of views in defining the new industrialization, as well as the driving forces and mechanisms for its implementation.

Scientists differentiate the priorities of the interpretation of the new industrialization (neoindustrialization) process.

Professor S. S. Gubanov in the development of the neoindustrial scientific paradigm considers neoindustrialization the second phase of industrialization, focusing on automation of productive forces, turning them into technetronic ones.

In a series of his articles, S. S. Gubanov advances the following main idea: the new industrialization is understood as a historically natural process of development of the productive forces, generally, after the completion of the first phase of industrialization - electrification. It represents the second phase of industrialization - automation, and computerization of the productive facilities. Due to computerization not only a working machine, but also the controlling one become automated, and the productive forces take the form of a technetronic triad: the employee - the computer - the automated means of production [12, 13, etc.].

According to S.S. Gubanov, the neoindustrial paradigm of modern development includes the theoretical and systemic basis that developed by 2000 through the discovery and analytical justification of the two systemic laws of neoindustrial progress. The first law is the law of machinery replacement of labor, established in the 1980s and empirically confirmed in 1994 on the materials of the USSR and the USA [14]. The second law is the law of vertical integration, also discovered in the 1980 s, but theoretically and strictly mathematically proven in 1998 [15].

S.S. Gubanov reveals the content characteristic of neoindustrialization, developed in the classical paradigm of knowledge of the mode of production, i.e. in the aspect of both productive forces and productive relations: "the paradigm of the mode of production, showing the concrete historical evolution of society from the lower stages to the higher, serves as a solid support for the scientific understanding of neoindustrialization as the second, digital phase of industrialization" [13].

Relying on the theory of the mode of production, S.S. Gubanov sees the following formula of modern development: the neoindustrialization of the productive forces and the vertical integration of productive relations.

Scientists of the Institute of Economics of the Russian Academy of Sciences, under the leadership of E.B. Lenchuk, the main content of the new industrialization is the process of spread of breakthrough technologies covering both the formation of new industries and sectors of the industrial economy that reproduce these breakthrough technologies and their spread in traditional industries and sectors of the economy $[16,17]$. It is proposed to consider several interrelated aspects of the process of the new industrialization: macroeconomic, structural, technological, resource, and institutional [16, p. 6-7].

The highlighted aspects of the new industrialization have an internal connection and interdependence, which should be taken into account when forming a policy of modernizing the industrial potential of the national economy and its regions.

To the position of the scientists of the Institute of Economics of the Russian Academy of Sciences is close the point of view of the professors D. E. Sorokin and S. A. Tolkachev, who classifies the neoindustrialization as a large-scale introduction of a complex of breakthrough NBIC technologies into the production process, a fundamental change in the essence of the industrial mode of production, which allows: dramatically improve the labor productivity in manufacturing industries; create new markets (however, some traditional activities will disappear); form global centers of rapid industrial growth; reduce the need for unskilled kinds of labor, which will aggravate the global problem of unemployment; strengthen the technological superiority of industrially advanced countries over the rest of the world [18, p. 88-89].

Scientists note that the neoindustrialization is a continuation of the technological revolution with the transfer of its main channel from the sphere of information financial services and $R \& D$ to the production process, with the formation of the sphere of intellectual production, when $a$ thought becomes a productive force. Many modern new technologies are at the junction of the NBIC group, for example, the construction of cellular and tissue structures 
(nano+bio), new information interfaces (info+cogno), bioinformatics (nano+info+bio).

As the main aim of re-industrialization ("new industrialization", "neoindustrialization") as an economic policy, which is a set of concrete measures, Professor S. D. Bodrunov sees the restoration of the role and place of industry in a country's economy as a basic component, as well as the priorities for the development of material production and the real sector of the economy on the basis of a new, advanced technological order within the framework of modernization of Russia [19, p. 84].

In the works by Professor V.M. Kulkov, the new industrialization acquires an integral character, including both re-industrialization, neoindustrialization, and superindustrialization [20, p. 81-85]. According to the scientist, to carry out a new industrialization in Russia means to act in all three directions indicated.

Each direction has its own sounding, so, reindustrialization in a broad sense is, firstly, the "second wind" of industrialism in our time, and secondly, it serves to designate a common developmental focus in connection with the need to have a reliable material and technical base of the national economy as the basis of the real sovereignty of the country. Neoindustrialization is the transition of the Russian economy to the level of the modern industrial basis and, in general, the world's advanced technological requirements. Superindustrialization (or advanced development) is a development line, connected primarily with the new (sixth) technological mode, the formation of which begins in the world. Its most significant elements will be biotechnology (especially molecular biotechnology and genetic engineering), nanotechnology, artificial intelligence systems with the active continuation of the development of space technologies, global information networks, nuclear energy, etc.

As A.I. Amosov rightly points out, the concepts of "reindustrialization", "innovative industrialization" and "new industrial development" reflect various aspects of modern industrialization. "In the notion of re-industrialization, the emphasis is put on restoring the industry that was destroyed in the process of de-industrialization. In the studies of innovative industrialization, attention is focused on innovation. In the phrase "new industrial development", the keyword is development. ... When elaborating the concept of new industrial development, it is necessary to take into account that innovation itself and industrialization itself serve only as a means of achieving goals. The aim of industrialization should be social and economic development. Thus, under the new industrial development is meant the transition to such a stage of industrialization, when innovation and the spread of machines, to a greater degree than before, are subject to the aims of social and economic development" [21, p. 22].

Scientists of the Ural scientific school of Academician A.I. Tatarkin understand the new industrialization as the dual synchronous process of creating new high-tech sectors of the economy and effective innovative renewal of traditional sectors, with the agreed qualitative and sequential changes between the technical and economic and social and institutional spheres implemented through interactive technological, social, environmental, political and managerial changes. [22, 23, 24, 25, 26, etc.].

Professor O. A. Romanova highlights the main tools of the new industrialization, which are nano-bio-info-cognitive technologies (NBIC-technologies), having interdisciplinary nature [26, p. 280]. These technologies, whose interpenetration has been called as NBIC-convergence, form a high-tech sector of the economy. It is these technologies, along with large-scale "digitalization", are the central element of the new technical and economic paradigm. At the same time, accounting the increasing importance of the person's role in all the processes of the new industrialization actualized the problem of the development of social and humanitarian (S) technologies and the convergence of humanitarian and natural scientific knowledge, what has been called as NBCIStechnologies.

Abroad, almost synchronously with the research of Russian scientists, scientific works directly devoted to the neoindustrial economy and its impact on the organization of production began to appear. Foreign scientists recognize that the service sector has become predominant, but immediately clarify that many are engaged in maintaining the industry in the sphere of services. According to the researchers, the neoindustrial nature is not some accidental aspect of the modern economy, but the very essence of it. In their opinion, "the modern neoindustrial economy demonstrates many of those features that are described in futuristic books. It is knowledge-intensive, as well as service-intensive, and extensively uses information technology, which develops and spreads at an incredible rate" [27, p. 3].

In the non-industrial form of the organization, along with production, related services oriented to the consumer and flexibility, planning and adaptation are included. Therefore, the conclusion follows: "Industrial society is going through a period of prolonged and radical transformation into a nonindustrial economy, caused by the increasing need for flexible production and satisfying the needs of consumers on the basis of opportunities provided by the development of information technologies" [27, p. 2].

The question of the driving forces, the mechanism and the priorities for the implementation of neoindustrialization remains discussible.

The question of determining the driving forces of neoindustrialization is actively discussed in the scientific literature. In the works by S. Gubanov, the main driving forces - the state and private capital - are considered; the thesis about the dominant role of the state is put forward.

The proposal to create a vertically integrated economy structure for the creation of the state-corporate sector as the core of the new system of social reproduction is also justified. The proposed offer on the transition to a policy of neoindustrialization, including the formation of a nationwide plan for the nationalization of strategic economic facilities, is controversial; at the same time, a deep justification for the need for vertical integration and the accumulation of an internal neoindustrialization fund does not raise doubts among scientists $[13,14,15]$. 
According to V. Ryazanov, the main driving force of neoindustrialization is the state - with the supporting role of market relations. In addition, in carrying out the neoindustrialization, the export-oriented model of economic growth should be reoriented to activate internal sources of development. This implies a stricter control over foreign economic relations, rational regulation of capital flows, etc. [28, p. 15].

The necessity of elaborating the state policy of the new industrialization is noted by the scientists of the Institute of Economics of the Ural Branch of the Russian Academy of Sciences: "For a meaningful moving forward in this direction, it is necessary to form a new long-term, verified state industrial policy, the most important task of which is to build a state system of legislative, financial, institutional and personnel support for the "new industrialization" [16, p. 54].

The choice of priorities for the new industrialization remains discussable.

A team of scientists, led by Academician V. V. Ivanter believes that the new industrialization should be initiated with the re-creation of the military-industrial complex, which will be followed by the rest as the multiplier. At the same time, industrial recovery should not be ensured at the expense of the population but using the accumulated serious financial resources. A significant part of them should be directed to the development of infrastructure [29].

Corresponding Member of the Russian Academy of Science V.A. Tsvetkov expressed another point of view on the priorities of the new industrialization of the Russian economy. As the starting point of modernization, he called the fuel and energy complex of Russia [30]. Noting that there are no outof-date production facilities, but there are out-of-date production methods, he suggests choosing as the most promising branches of the mining industry (primarily the fuel and energy complex) and the national infrastructure (transport, telecommunications, energy). In his opinion, firstly, they have external competitiveness, and secondly, they have necessary and sufficient conditions for transformation; thirdly, they have a cumulative synergetic development effect and at the same time, they are the most powerful locomotives for innovations.

On this issue, we are close to the position of the scientists of the Institute of Economics of the Russian Academy of Sciences, who note: "A country with a sufficiently large market, claiming to be one of the subjects in the world economy, cannot specialize in two or three advanced industries or technologies. It should take a worthy position in a wide range of industries. This becomes especially evident in the context of the worsening confrontation between Russia and the West in connection with the increasingly complicated geopolitical situation in the world, which Russia will be able to withstand only if a diversified, technologically independent and competitive economy is formed, oriented to the development of both promising and traditional technological sectors" [16, p. 86].

We must agree with the opinion of K. Perez, a well-known researcher in the theory of large waves and innovation cycles, which points out that the development of industries of different technological structures solves different tasks: the future wave industries guarantee independence and selfsufficiency in the future, the current wave industries provide basic infrastructure and technical support of the economy, "old" industries are the main source of employment [31].

Our review of the literature has shown that within the formation of the scientific paradigm, most authors at the macroeconomic (country) level study the processes of the new industrialization (neoindustrialization). The problems of investigating the new industrialization in the space of regions and macroregions are practically not affected. It is possible to single out only some of the works of the Ural scientists A. I. Tatarkin, O. A. Romanova, I. V. Makarova, and V. V. Akberdina, devoted to this problem.

In particular, A.I. Tatarkin and O.A. Romanova proposed the definition of the process of the neoindustrialization of the regional economy as a process of creating its new sectors, the effective renovation of traditional industries and fields of process industry, but also agreed qualitative changes in the entire system of social relations in accordance with the requirements of the time [32, p. thirty].

\section{CONCLUSION}

Based on the above, we formulate the author's vision of the new industrialization.

We classify the new industrialization in the economic space of the region as a twofold process that, on the one hand, involves an innovative renewal of traditional basic industries (the process of re-industrialization), and on the other, the creation of new high-tech manufactures of the fifth and sixth technological structures (the process of neoindustrialization) which aims to rise living standards of the population as the result of increased production efficiency.

The main mechanism for the implementation of the new industrialization in the economic space of the region is an active state and regional policy.

We believe that only on the basis of the new industrialization policy it is possible to ensure the economic growth, to achieve the competitiveness of the old industrial regions, a typical representative of which is the Ural macroregion. In a series of scientific papers, we presented a detailed study of factors of deindustrialization, as well as key directions of the new industrialization of the Ural macroregion. [33, 34, etc.].

\section{Acknowledgment}

The research was conducted with the financial support of the Russian Foundation for Basic Research under scientific project No. 18-010-00833 A "Neoindustrialization in the space of the macroregion in the context of the cyclic wave methodology (on the example of Ural)". 


\section{References}

[1] Encyclopedic dictionary of philosophy. M., 1999.

[2] Kuhn, T. The structure of scientific revolutions. M., 2002.

[3] Osipov, Yu. M. Neoindustrialization: essence, meaning, and mechanism of realization // Philosophy of economy. 2013. No. 3. P. 283-288.

[4] Smith, A. An Inquiry into the Nature and Causes of the Wealth of Nations. The Glasgow Edition of Adam Smith. Edition II. Oxford: Clarendon Press. 1979.

[5] Gubanov, S.S. From the export resource-based model to the neoindustrial economic system // Economic revival of Russia. 2015. No. 4 (46). P. 48-59.

[6] The Great economic dictionary, Ed. A.N. Azriliyan. M., 2004.

[7] Ushakov, D.A. The Great explanatory dictionary of the modern Russian language. M., 2008.

[8] Rumyantseva, E.E. New economic encyclopedia. M., 2005.

[9] Erlich, A. Discussion on industrialization in the USSR. 1927-1928. M., 2010.

[10] Sukharev, O.S. Economic theory of industrialization // Bulletin of Perm University. Ser. Economy. 2015. Vol. 2 (25). P. 6-14.

[11] Bazarov, V. Principles of constructing a long-term plan. // Planned economy. 1928. No. 2. P. 38-63.

[12] Gubanov, S. Neoindustrialization plus vertical integration (on the formula for the development of Russia) // Economist. 2008. P. 3-27.

[13] Gubanov, S. Neoindustrial developmental paradigm: a brief generalization // Ekonomist. 2017. No. 11. P 22-39.

[14] Gubanov, S. Level of productive forces: the experience of measurement and intercountry analysis) / / Economist. 1994. No. 8. P. 15-29

[15] Gubanov, S. Perspective - transition to a state-corporate economy // Economist. 1998. No. 6. P. 70-83.

[16] New industrialization as a condition for the formation of an innovative model for the development of the Russian economy. Scientific report. Project coordinator E.B. Lenchuk. M., 2014.

[17] New industrial policy of Russia in the context of ensuring technological independence / Responsible. Ed. E.B. Lenchuk. SPb., 2016.

[18] Sorokin, D. E., Tolkachev, S. A. Conditions and factors of effective reindustrialization and industrial policy of Russia // Economic revival of Russia. 2015. No. 4 (46). P. 88-89.

[19] Bodrunov, S. D. The future. New industrial society: reboot. SPb., 2016.
[20] Kulkov, V. M. New industrialization in the context of Russia's economic development // Economics. Taxes. Law. 2015. No. 2. P. 81-85.

[21] Amosov, A. I. On the possibility of achieving target indicators of the new industrial development // Bulletin of the Institute of Economics of the Russian Academy of Sciences. 2014. No. 4. P. 21-32.

[22] Tatarkin, A.I., Andreeva, E., Ratner, A. Imperatives of modern economic development: world trends and Russian realities // Issues of economics. 2014. No. 5. P. 121-131.

[23] Tatarkin, A. I., Romanova, O.A. New industrialization of the Russian economy // Bulletin of the Ural Federal University. Series: Economics and Management. 2014. No. 3. P. 13-21.

[24] Romanova, O. A. Strategic vector of the economic dynamics of the industrial region // Economics of the region. 2014. No. 1. P. 43-56.

[25] Tatarkin, A. I. New industrialization of the Russian economy: the need for development or the challenges of time // The economic revival of Russia. 2015. No. 2 (44). P. 20-31.

[26] Romanova, O. A. Innovative paradigm of the new industrialization in the conditions of formation of an integrated world economic structure // Economy of the region. 2017. Vol. 13, edition 1. P. 276-289.

[27] Ekstedt, E., Lundin, R.A., Soderholm, A., Wirdenius, H. Neoindustrial Organizing: Renewal by Action and Knowledge Formation in a Projectintensive Economy. London: Routledge. 1999.

[28] Ryazanov, V. From the rental economy to the new industrialization of Russia // The Economist. 2011. No. 8. P. 3-17.

[29] New economic policy - Policy of economic growth / Ed. V.V. Ivanter. M., 2013.

[30] Tsvetkov, V. We must turn our "gaps" into benefits // The Russian Federation today. 2013. No. 11. P. 24 - 27.

[31] Perez, K. Technological revolutions and financial capital. Dynamics of bubbles and periods of prosperity. M., 2013.

[32] Tatarkin, A., Romanova, O. On possibilities and mechanism of neoindustrialization of old industrial regions // The Economist. 2013. No. 1. P. 21-38

[33] Silin, Ya. P., Animitsa, E. G., Novikova, N. V. Regional aspects of the new industrialization // Economy of the region. 2017. Vol. 13. No. 3. P. 684-696.

[34] Silin, Ya. P., Animitsa, E. G., Novikova, N. V. Trends in the development of the economic space of the Urals macroregion. // The Supervisor. 2017. No. 2 (66). P. 2-11. 